\title{
THE URGENCY OF THE ROLE OF ORGANIZATIONAL MOTIVATION IN MANAGING PRIVATE ISLAMIC EDUCATION INSTITUTIONS IN ERA 4.0
}

\author{
Hisam Ahyani \\ STAI Miftahul Huda Al Azhar Banjar, Indonesia \\ Corresponding Author : hisamahyani@gmail.com \\ Dodo Suhada \\ STAI Miftahul Huda Al Azhar Banjar, Indonesia \\ Author : e-mail: 01dodosuhada@gmail.com \\ Syamsudin \\ STAI Miftahul Huda Al Azhar Banjar, Indonesia \\ Author : e-mail: ellsyam234@gmail.com \\ Sartono \\ STAI Miftahul Huda Al Azhar Banjar, Indonesia \\ Author : e-mail: sartonocakep4@gmail.com
}

\begin{abstract}
ABSTRAK
Lembaga pendidikan Islam menjadi sebuah keniscayaan, yang mana lembaga pendidikan islam di Indonesia terutama dalam hal eksistensi lembaga pendidikan yang sangat dibutuhkan oleh masyarakat dewasa ini, dimana era 4.0 (disrupsi) dan Scoety 5.0 juga menjadi sebuah keniscayaan yang perlu dipertimbangkan dalam menjaga eksistensi di setiap lembaga pendidikan terutama lembaga pendidikan yang berstatus swasta yang kini masih eksis hingga sekarang. Alhasil keberhasilan dalam memanaj suatu organisasi khususnya di lembaga pendidikan islam diharapkan mampu mendongkrak tingkat kesejahteraan para SDM dan juga lembaga yang di kelola oleh lembaga pendidikan tersebut. Seiring perkembangan zaman yang serba maju seperti sekarang ini yang telah memasuki era disrupsi 4.0 dimana masyarakatnya telah menjadi Masyarakat digital (Scoety 5.0) maka perlu strategi khusus dalam memanaj suatu lembaga pendidikan islam, semisal dengan meningkatkan fasilitas pembelajaran dan sarana serta prasarana yang memadai agar tidak tertinggal dengan lembaga-lembaga pendidikan islam lainnya di Indonesia dewasa ini.
\end{abstract}

Kata Kunci : Motivasi organisasi, Manajemen Pendidikan Islam, Era 4.0, 5.0

\begin{abstract}
The importance of the Role of Organizational Motivation in Managing Private Islamic Educational Institutions, especially in Era 4.0 is a necessity, where many private Islamic higher education institutions are now established to compete with each other, where the 4.0 era (disruption) which is now present in the midst of Society 5.0 needs a strategy specifically to maintain
\end{abstract}


the existence in every private Islamic higher education institution. The purpose of this study is to find out the implementation of organizational motivation by managers of private Islamic universities in managing private Islamic educational institutions in Era 4.0 so that they can still exist and be able to compete; To find out what obstacles are faced by managers of private Islamic universities in maintaining the existence of their institutions in Era 4.0; and to find out the solutions offered to overcome these obstacles. The method used in this research is library research, with data sources obtained from various literature books, journals, internet related to the Urgency of the Role of Organizational Motivation by managers of private Islamic universities in Indonesia in Managing their Institutions in Era 4.0. The results show that the success of a manager of a private Islamic higher education institution is the ability of higher education managers to manage the institutions they lead, one of which is through the role of motivation for the human resources they manage and using a unique and attractive management model in order to improve the performance of human resources, facilities, facilities and adequate infrastructure to be able to compete with other private Islamic higher education institutions in Indonesia.

Keywords: Organizational motivation, Islamic Education Management, Era $4.0,5.0$

\section{INTRODUCTION}

The existence of private Islamic higher education institutions in Indonesia has become a necessity where the institutions that are currently emerging have invited the public to choose which private Islamic higher education institutions they are interested in. Therefore, higher education institutions that now exist in Indonesia must be able to maintain the values and norms that apply in society and according to the rules of the Qur'an. So that motivation is a psychological impulse that is able to direct someone towards a desired goal. With sincere dedication motivation, educators and education staff will be able to work optimally. Managers of private Islamic higher education institutions in Indonesia need to prioritize efforts to immediately implement the role of motivation for human resources, improve facilities, facilities and adequate infrastructure to support the existence of institutions led by every manager of private Islamic universities. One of the things that can be done by the management of private Islamic tertiary institutions in Indonesia to maintain the existence of their institutions is through various uses of motivational theories in managing higher education they manage.

An organization is a group of people who work together to achieve a common goal. In a school environment, the most important element that must be managed is the people associated with it, especially teachers, students, and their work. In particular, humans are the most important element of all organizational elements, because only humans have dynamic characteristics. Therefore, to achieve the goal, resources are needed. These resources include natural resources, financial resources, science and 
technology resources and human resources. Among these resources, human resources are considered the most important because they can affect the efficiency and effectiveness of the organization and are the main expenses of the organization in carrying out its activities. Therefore, it is necessary to have a special intake in an organization, one of which can be done through motivation, this is as exemplified in research launched by (Zairotun, 2019) that work motivation by leaders in an institution is very necessary, this is because superior human resources can be created through the motivation of the management of the institution concerned.

A research proves that there is a positive and significant effect between work motivation on employee performance, and also between organizational commitment to employee performance (Susita et al., 2020). Other research as has been done by (Putri et al., 2019) explains that there are at least 5 roles of motivation in improving employee performance, namely: 1) Opportunities for development and growth at work aim to improve employee performance, improve employee service quality, increase creativity in the work of employees, increasing the potential of employees at work. 2) Norms for measuring work skills and good work results aim to improve employee performance. 3) Measurement of skills and good work results if active in work, able to carry out tasks that have been set by the leadership. 4) Information as feedback to improve and improve their activities at work aims to provide information to employees who have made mistakes in order to correct mistakes that have been made, improve the quality of employee work. 5) Opportunities to participate in the decision process can increase work motivation, aiming to provide opportunities for employees of freedom, freedom in the sense of following the rules set by the company. Role stability aims to streamline employee work, understand and understand the tasks that must be done, provide responsibility for the work given by the leadership, improve good ideas at work.

Studies related to motivation which incidentally is a vital element in an organization. Motivation varies from one individual to another, depending on many factors such as ambition, educational background, goals to be achieved, and social environment. Motivation comes from a person's strong desire to achieve certain goals. No matter what difficulties must be overcome, but rather foster positive thoughts and obey the course of activities so that organizational goals can be achieved (Kasim, 2014). Therefore, the importance of motivation, whether carried out by individuals or groups in an organization, is a necessity that must be realized early on (Muslih, 2020).

Regarding human resources, which incidentally is a group / individual who works in an organization should receive more attention, this is intended so that the organization's journey is as expected. Attention in question is "motivation", where motivation has an important role in building a person's performance more optimally. In addition to human resources, in order to maintain the existence of private Islamic higher education institutions in Indonesia, university managers also need to improve facilities, adequate infrastructure for the realization of the existence of private Islamic higher education institutions that are now widely 
established. From the above background where the all-digital era (4.0) comes with various challenges that must be faced by higher education managers, the researchers will explore and uncover the Urgency of the Role of Organizational Motivation in Managing Private Islamic Educational Institutions in Era 4.0 which is very necessary. in order to maintain the existence of a superior private Islamic higher education institution and remain in demand by the Society 5.0. Therefore, the authors ask several research questions which are summarized in detail as follows: 1) How is the Implementation of Organizational Motivation carried out by managers of private Islamic universities in Managing Private Islamic Educational Institutions in Era 4.0 in order to continue to exist and be able to compete?; and What are the obstacles faced by managers of private Islamic universities in maintaining the existence of their institutions in Era 4.0?; and how are the solutions offered to overcome these obstacles?. The objectives of this study are, first, to find out the implementation of Organizational Motivation carried out by managers of private Islamic universities in Managing Private Islamic Educational Institutions in Era 4.0 in order to continue to exist and be able to compete; second, to find out what obstacles are faced by managers of private Islamic universities in maintaining the existence of their institutions in Era 4.0; third, to find out the solutions offered to overcome these obstacles.

This type of research is library research. The nature of the study in this article is narrative-descriptive-qualitative about the Urgency of the Role of Organizational Motivation in Managing Private Islamic Higher Education Institutions in Era 4.0 which is very necessary in order to maintain the existence of an institution. Private Islamic colleges that excel and remain in demand by Society 5.0, which the authors collect from various sources/references relevant to the theme being discussed, one of which is from a book by (Turney et al., 1992) entitled "The School Manager (Educational Management Roles \& Tasks) The School Manager". In the theory of needs, as Abraham Maslow's opinion cited by (Zairotun, 2019) in his journal explains, the variation in human needs is seen as arranged in the form of a hierarchy or level. Each level of need can be met only if the previous level has been relatively satisfied. This means that the role of managers of private Islamic universities is very important in motivating the human resources they manage, and also improving facilities, facilities, infrastructure to support the existence of the higher education institutions they manage.

\section{RESEARCH METHODS}

This type of research is library research. The nature of the study in this article is narrative-descriptive-qualitative about the Urgency of the Role of Organizational Motivation in Managing Private Islamic Higher Education Institutions in Era 4.0 which is very necessary in order to maintain the existence of an institution. Private Islamic colleges that excel and remain in demand by Society 5.0, which the authors collect from various sources/references relevant to the theme being discussed, one of which is from a book by (Turney et al., 1992) entitled "The School Manager 
(Educational Management Roles \& Tasks) The School Manager". In the theory of needs, as Abraham Maslow's opinion cited by (Zairotun, 2019) in his journal explains, the variation in human needs is seen as arranged in the form of a hierarchy or level. Each level of need can be met only if the previous level has been relatively satisfied. This means that the role of managers of private Islamic universities is very important in motivating the human resources they manage, and also improving facilities, facilities, infrastructure to support the existence of the higher education institutions they manage.

Furthermore, the expectancy theory is assumed that "the higher one's expectations for success, the greater the motivational force that can lead to increased performance in working for human resources in an Islamic higher education institution. Furthermore, in the theory of goals / goal setting that puts forward the source of motivational strength, namely in terms of challenging goals so that a person is indirectly indoctrinated "Ghirah his spirit" in achieving the goals he wants. Furthermore, in terms of intrinsic motivation, which becomes a shared desire for $H R$ to increase work motivation, it is by enjoying the satisfaction of doing a certain action, so that extrinsic motivation which incidentally can generate desire (desire) to pursue a dream/goal caused by rewards/rewards of a financial nature such as an increase in salary and popularity for HR in a certain private Islamic higher education institution.

\section{DISCUSSION}

A. Implementation of Organizational Motivation Theories in Private Islamic Higher Education Institutions in Era 4.0

Motivation is the whole process of providing motivation to work to subordinates in such a way that they want to work sincerely for the achievement of organizational goals efficiently and economically (Siagian, 1994: 128). Motivation is closely related to the expression of human needs. Maslow's Hierarchy Theory (1970) has long been used as a means of better understanding and exploiting sources of motivation for people in various contexts. Hierarchies are often represented as pyramids, built on a foundation of basic physiological and safety needs, and extending upward through a sense of belonging and self-esteem to the highest levels of selfactualization. So that the implementation of Organizational Motivation carried out by managers of private Islamic universities in Managing Private Islamic Higher Education Institutions in Era 4.0 must be realized early on.

Maslow argued that an individual's full enthusiasm and energy will be directed towards self-actualization needs only if lower-level needs have been met first. Good physical condition by maintaining health and includes the need for food, clean air, rest, exercise and protection from the elements. A good physical environment, together with the provision of physical activity and adequate food in the canteen, will help meet this level of need in the school environment. Security includes needs such as protection from physical harm and the sense of physical security that comes from living in a supportive and predictable environment (Murphy et al., 1985). The motivational maintenance theory or "motivational maintenance theory" is 
largely derived from studies involving development and accountants (calculation) (Herzberg et al., 1967). Herzberg drew a distinction between motivating and nurturing factors. Motivators usually stimulate positive performance and attitude. The maintenance factor is not motivating by itself but must be met to a reasonable extent for the motivator to be operational. The following table shows the relationship between the two theories.

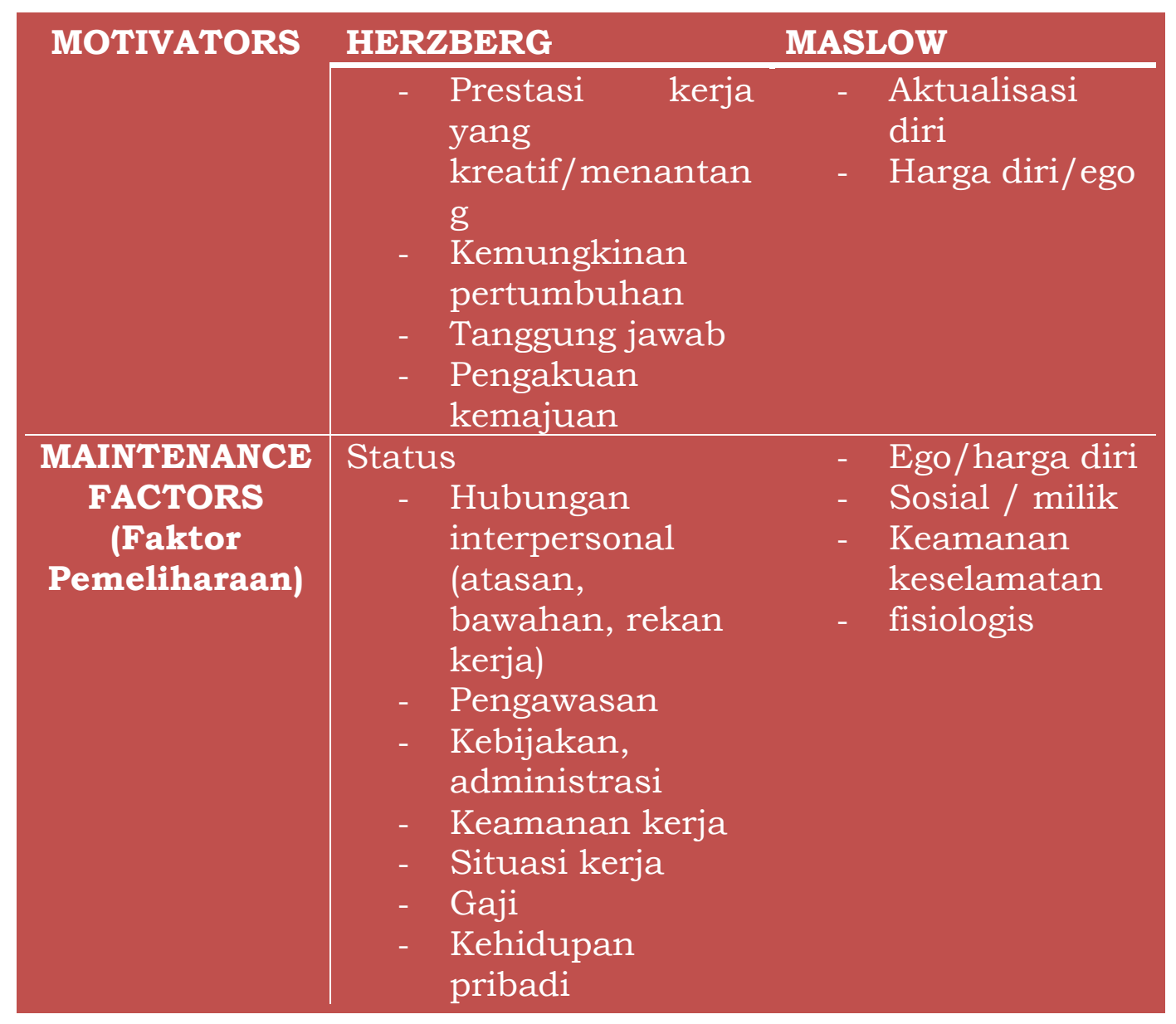

In particular, wages or income have been shown to have a motivating effect, and are often associated with various self-esteem needs such as status and societal recognition, which Herzberg considers motivators. While wages are needed to achieve a sense of security and meet physiological needs. In terms of as a form of Contribution of Private Islamic Higher Education Managers to the Development of Islamic Education in Indonesia as research launched by (Fahrurrozi, 2017) one of them is by establishing private Islamic higher education institutions that are able to answer the needs of the community, for example by freeing all costs education for the dhuafah, the poor and for people of all people to be able to take part in advancing education in certain areas. With the establishment of this higher education institution, its establishment is based on the concept of rahmatan lil aalamin and the concept of an organism that refers to the qur'an and hadith, as well as consensus. And universities have a very urgent role in the development of Islamic education. Thus, the application of motivation theory 
to every manager of higher education institutions in Indonesia is expected to be an inspiration for higher education leaders towards superior and innovative institutional organizations, as well as beneficial for the homeland and nation. But in reality, in this digital era, it is necessary to develop adequate facilities, facilities and infrastructure to support the existence of higher education institutions in Indonesia.

In addition, the quality in terms of competing in higher education institutions, especially private campuses in Indonesia, also needs to be considered and improved with adequate facilities, infrastructure and facilities. For example, by creating a quality-based Islamic campus program, so that the education that is being undertaken by the institution, the head of the institution at a university will be able to answer the challenges in the future (Lubis \& Pratama, 2021). Thus, it is necessary to apply motivation for higher education management leaders in preparing inputs for their subordinates to continue to struggle together to raise the institution they lead. For example, if the salary of a teacher / lecturer can result in low motivation (because they have to look for additional), so that it has an impact on the quality of higher education services they manage (Rusdiana, 2021).

B. Aims (Purpose) application of Motivation in Private Islamic Higher Education Institutions in Era 4.0

The motivating role is mainly related to work behavior by utilizing internal and external factors that will initiate and maintain the work of participants for whom school managers are responsible, especially teachers and students. The specific objectives of this role are to: 1). Ensure the commitment of all participants, both individuals and groups, to the stated and agreed mission of the school. 2). Creating conditions that will give active effort to the efforts of teachers and students to achieve the goals of school education. 3). Maintain a level of motivation that will ensure that staff stick with tasks that are understood and accepted, thereby maintaining good morale in the school. 4). Set the right example in carrying out tasks with enthusiasm, showing warmth and effective interpersonal relationships. 5). Cultivate a positive school climate through a sense of achievement that arises when participants experience success in implementing cooperative action plans.

So that the Aims (Purpose) application of Motivation in Private Islamic Higher Education Institutions in Era 4.0 carried out by university managers, especially managers of private Islamic universities is to build superior human resources and is expected to motivate the managers of these universities to immediately realize motivation to $\mathrm{HR}$ in order to further improve the welfare of the human resources who work in certain institutions. So, in order to apply motivation to private Islamic higher education institutions in the 4.0 era, the goal is to improve the quality of public services in order to attract public sympathy to join the institutions they are managing (Wulan \& Mustam, 2017). In terms of improving the organization that is being managed, this is also necessary because every organization and leadership requires a clear goal (vision) in order to increase 
existence in a private Islamic higher education institution in Indonesia. exemplified in the development of unique and interesting tourism-based tourism, it is the service and facilities, facilities, and infrastructure that need to be emphasized (Prafitri \& Damayanti, 2016). Likewise in management, services which are the motivational goals for managers of private Islamic universities in Indonesia need to be improved.

C. Implementation of the Principles of Usage in Organizational Motivation in Private Islamic Higher Education Institutions

Implementation of the Principles of Usage in Organizational Motivation by Managers of Private Islamic Higher Education can be done by applying the role of organizational motivation from an early age. There are principles associated with a general style of management that apply to this and to each of the manager's roles. 1). Warmth and enthusiasm ie Through the literature, there is always an underlined about how important it is to encourage interaction and a sense of cooperation, whether in big business or institutions such as schools. This emphasis is evident in specific areas such as encouraging creativity among students, encouraging enthusiasm and challenge to teach, and the positive climate achieved through an emphasis on praise and appreciation instead of using criticism. 2). Consistent Modeling, as stated by Bandura (1977) who identified the importance of learning through observing the behavior of others. Imitation, especially when reinforced, greatly affects both attitudes and ways of behaving. For teachers and administrators, effect modeling is very important for all participants in the school environment. Blumberg and Greenfield (1986) identified, as one of the important factors in winning principals' support for their own behavioral model vision, as well as consistent commitment through their actions to realize the school's mission. The media must match the message. A manager's best vision can be completely shattered by inappropriate behavior. 3). Awareness Of Human Needs (Awareness of Human Needs), namely as the opinion of Maslow's Hierarchy $(1959,1970)$ in his research which shows that those in management positions must understand the various levels at which personal needs function. Principals in particular should recognize the need to create conditions in which basic physiological, safety and sense of belonging needs are met before stronger motivation for teachers and students comes from fulfilling self-esteem and self-actualization needs. A level of self-awareness is required in understanding one's own need for power, affiliation and achievement (McClelland, 1961), and respecting the same needs in other staff. This sensitivity will lead to a commitment to empower others, to realize higher-level needs in the school environment. 4). Maintenance Of Equity, this means when in recent years, considerable attention has been paid in policy statements to issues related to equity and equal opportunity. For managers (as for classroom teachers), the main difficulty lies in ensuring that their perceived attention, interest and reinforcement are equitably distributed (Turney et al., 1982, 1983). The application of these relevant principles will depend on sufficient insight and understanding. Especially for staff, the perception that rewards and recognition for work done is the 
same as that given to others, in the same position can contribute greatly to job satisfaction (Koontz et al., 1984).

For this reason, in terms of implementing the Principles of Usage in Organizational Motivation in Private Islamic Higher Education institutions, it can help university managers to make their own satisfaction for HR and the educational institutions they lead. For example, by developing student organizations in supporting the existence of the higher education institutions they are managing (Cahyorinartri, 2018). In addition, with superior motivation from the campus, it can also develop the potential of students who are determined to study at the universities they manage. Especially in the world of education today in the 4.0 era (disruption also cannot be separated from the management system. In education alone there have been several fundamental weaknesses in its implementation in Indonesia, and it is these fundamental weaknesses that make it a challenge for university managers they manage, including the field of management which includes the dimensions of process and substance At the process level, such as planning, implementation, and evaluation has not been carried out with strict work procedures At the substantive level, such as personnel, finance, facilities and infrastructure, learning instruments, auxiliary services, library services, and so on, not only is the substance not comprehensive, but the success criteria for each of them have not been determined in accordance with the principles in the scope of education (Amirudin, 2017).

D. Implementation of Tasks (Tasks in Applying the Role of Motivation) for Private Islamic Higher Education Institutions

In carrying out the motivational role, the main focus is on four main tasks, namely: 1). Encouraging involvement (Encouraging involvement), includes efforts to maintain and recognize the importance of effective interaction and cooperative efforts of teachers in pursuing school goals. 2). Enhancing teaching conditions, which includes creating the best context for enabling development, ensuring basic needs are met. 3). Supporting individuals and groups, which includes recognition of achievements and the need to meet the needs of both individuals and certain groups in schools. 4). Fostering climate and morale (Climate and moral development), which is primarily concerned with providing challenges and maintaining a positive school attitude and tone. Furthermore, these tasks are divided into several sub-tasks, as shown in the table below:

\begin{tabular}{|c|c|c|c|}
\hline \multicolumn{4}{|c|}{ MOTIVATING (MOTIVASI) } \\
\hline $\begin{array}{l}\text { Mendorong } \\
\text { keterlibatan }\end{array}$ & $\begin{array}{c}\text { Meningkatkan } \\
\text { kondisi } \\
\text { pengajaran }\end{array}$ & $\begin{array}{c}\text { Mendukung } \\
\text { individu dan } \\
\text { kelompok }\end{array}$ & $\begin{array}{l}\text { Pembinaan iklim } \\
\text { dan moral }\end{array}$ \\
\hline $\begin{array}{l}\text { Dnhancing } \\
\text { relationship } \\
\text { (meningkatka } \\
\text { n hubungan) }\end{array}$ & $\begin{array}{l}\text { - Meeting basic } \\
\text { needs } \\
\text { (memenuhi } \\
\text { kebutuhan }\end{array}$ & $\begin{array}{l}\text { - Providing } \\
\text { incentives } \\
\text { (memberikan } \\
\text { insentif) }\end{array}$ & $\begin{array}{l}\text { - Sustaining } \\
\text { positive } \\
\text { attitudes } \\
\text { (mempertahank }\end{array}$ \\
\hline
\end{tabular}




\begin{tabular}{|c|c|c|c|}
\hline $\begin{array}{l}\text { - Encouraging } \\
\text { participation } \\
\text { (mendorong } \\
\text { partisipasi) } \\
\text { - Harnessing } \\
\text { personal } \\
\text { interest } \\
\text { (memanfaatka } \\
\text { n kepentingan } \\
\text { pribadi) } \\
\text { Facilitating } \\
\text { cooperation } \\
\text { (memfasilitasi } \\
\text { kerjasama) } \\
\text { Dealing with } \\
\text { conflict } \\
\text { (menangani } \\
\text { konflik) }\end{array}$ & $\begin{array}{l}\text { dasar) } \\
\text { - Providing } \\
\text { feedback } \\
\text { (memberikan } \\
\text { umpan balik) } \\
\text { - Dealing with } \\
\text { anxiety } \\
\text { (mengatasi } \\
\text { kecemasan) } \\
\text { - Encouraging } \\
\text { professional } \\
\text { growth } \\
\text { (mendorong } \\
\text { kebutuhan } \\
\text { professional) }\end{array}$ & $\begin{array}{l}\text { - Recognizing } \\
\text { achievements } \\
\text { (Mengakui } \\
\text { pencapaian) } \\
\text { - Fostering self- } \\
\text { image } \\
\text { (menumbuhka } \\
\text { n citra) } \\
\text { - Dealing with } \\
\text { anxiety } \\
\text { (mengatasi } \\
\text { kecemasan) }\end{array}$ & 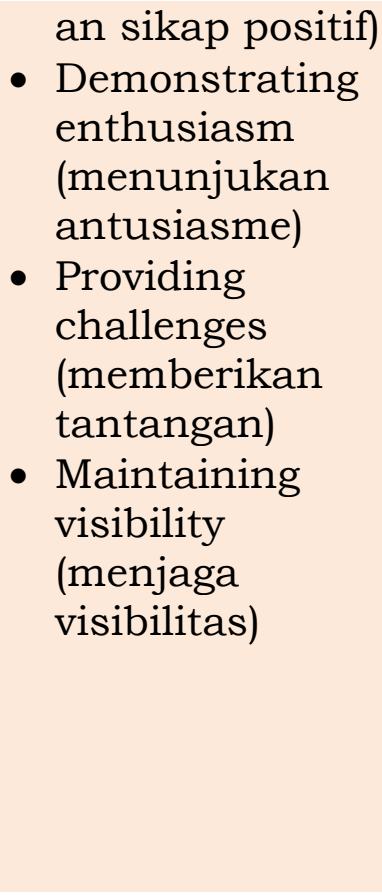 \\
\hline
\end{tabular}

From the above task, it is hoped that the Implementation of Tasks (Tasks in Applying the Role of Motivation) which are applied to Private Islamic Higher Education Institutions can help increase the motivation of higher education managers, increase human resources, increase motivation for prospective new students to enroll as students in educational institutions. A well-managed and directed private Islamic university that is adapted to the demands of the times. For example, by increasing the professional competence of human resources, as well as awarding outstanding lecturers, as well as conducting periodic evaluations in the private Islamic university they lead (Sufianti \& Permana, 2015).

E. Encouraging involvement in the Higher Education environment (Involvement of all stakeholders)

Enhancing relationships that present a strong social motive is one way to encourage active involvement from participants. In much of the literature on school effectiveness, there are ongoing references to the importance of good relationships with students. Schools that run well are generally led by principals who are known for their concern for the interests of students and values such as fairness or decency. Encouraging participation is a key aspect of motivating through active engagement, especially by developing opportunities for decision making. Giving staff and students the right to be involved in decision-making and making helps build commitment to the school's goals.

Harnessing personal interests also allows principals and other staff with specific responsibilities to encourage high-level involvement in the school environment. Motivation is closely related to individual differences and needs (Gage \& Berliner, 1984). In any school, there will be stark differences between staff and students with respect to interests, talents, 
skills and preferences. Managers need flexibility and sensitivity in making judgments about the strengths of working in certain situations. Principals in particular, need to know the special and distinctive talents of their staff and students. Facilitating collaboration among group members is another important avenue for effective active engagement. In the planning role, the motivational power of participation in planning has been established (Porter, 1987). Collaboration is key to seeing plans implemented, especially when there are changes. Not only must teachers work together effectively, but there must also be closer cooperation between the school and its community members.

Dealing with conflict has become an important part of the manager's role in various contexts. Disagreements are bound to arise when so many different personalities are involved. Most likely, the biggest barriers to selfesteem and self-actualization result from misunderstandings, complaints and poor human relations, which require managers to develop skills in dealing with conflict. Principals and senior staff need to develop adequate counseling skills, and learn to listen to all parties involved impartially, so that they get a clear picture of the actual issues at stake (Brammer, 1979; Young, 1978). When conflict problems occur, the principal must face the parties concerned and find a solution (Kurtz, 1988). In the case of Encouraging Involvement (Encouraging involvement) for each stakeholder in an institution, an example is such as the manager of a university making a regulation with a collaboration model for lecturers with other lecturers in the plan, do, and see process. So that it is expected to encourage students to participate more in the group learning process and classical learning (Margono, 2014). Another thing that can be done in terms of collaboration used to support motivation for private Islamic higher education institutions is to conduct student centered learning (Johanes, 2018). This is very useful to raise motivation for human resources and educational institutions that exist in Indonesia, so that students' interest in learning increases.

F. Implementation of the Role of Organizational Motivation through Enhancing Teaching Conditions (Improving Teaching Conditions)

Improving teaching conditions (Enhancing teaching conditions) the focus is on people's support. The sub-tasks are as follows: Meeting basic needs by addressing the maintenance factors identified above will improve working conditions in schools and provide practical support. Meeting other basic needs often depends on the education system including things like lighting, clean air, health, seating and immediate.

Providing feedback makes it possible to address other maintenance factors that fall within the scope of working conditions, relationships and supervision. Encouraging professional growth (Encouraging professional growth) enables the fulfillment of needs such as recognition, status, and advancement. This aspect of technical support and reserves is clearly linked to effective monitoring and feedback on development and will again depend on the capacity of staff to be responsible. This is as research proclaimed by (Habibie, 2015) that quality human resources can support development in an educational institution, which can be done continuously and in 
accordance with the needs of the community. Another thing as research conducted by (Emda, 2018) that the position of student learning motivation in learning for students can motivate students to be active in learning. In this case, students in achieving the learning objectives that have been set then the emergence of motivation is not solely from the students themselves but the teacher must involve themselves to motivate student learning. The existence of motivation will provide enthusiasm so that students will know the direction of learning. Learning motivation can arise if students have a desire to learn. Therefore, both intrinsic and extrinsic motivation must exist in students so that the learning objectives that have been formulated can be achieved optimally. This is a form of real evidence of the improvement of teaching conditions in private Islamic universities.

\section{G. Supporting Individuals and Groups in the College Environment}

In realizing the school's mission, principals have a responsibility not only to share with others, but to provide encouragement, resources and assistance for problem solving (Fullan, 1991). This aspect focuses on the personal aspect, while the previous aspect focuses more on technical and material support (enhancing teaching conditions). The sub-tasks are providing incentives, recognizing achievements, fostering self-image, dealing with anxiety. Providing incentives is a form of extrinsic motivation which can be in the form of receiving praise or recognition from fellow teachers or superiors, being promoted or getting a salary increase. Recognizing achievements, allows principals to motivate students or staff in a variety of ways. Extrinsic motivation will be generated when performance is recognized by others, especially by someone with a recognized status. It is of utmost importance that the achievements of individuals and groups of even the smallest kind are recognized. Fostering a self-image (fosterinf self-image) is another way to increase the positive effect on motivation.

Maslow (1959, 1970) and Herzberg et al. (1967) emphasized that people strive for success and competence, and try to avoid failure which results in low self-esteem. To encourage a positive view of oneself, person-toperson contact is required, with sufficient words of encouragement to the individual. Dealing with anxiety allows those in positions of responsibility to help with higher needs and motives be very beneficial especially by reducing stress on the individual as much as possible. Leaders need to be skilled and careful listeners who can demonstrate a willingness to take appropriate action (Sparkers, 1983). Sometimes, there will be a need to help individuals sort out their priorities and to provide personal counselling, or at least point out avenues in which those who show indications of excessive tension can seek help.

H. Implementation of the Role of Organizational Motivation through Fostering Climate And Morale in Higher Education

Establishing effective working groups (Snyder, 1984) responsible for planning, problem identification and decision making, along with quality control, also helps a lot to develop the climate. Managers have a very significant contribution to their formation and maintenance and recognition 
is given for successful efforts. The Sub-tasks identified to encourage climate and improve morale include the following: 1) maintain a positive attitude (sustaining positive attitudes); 2) show enthusiasm (demonstrating enthusiasm); 3) provide challenges (providing challenges); 4) maintain visibility Maintaining a positive attitude (Sustaining positive attitudes) will greatly help maintain the climate and morale. For example, the sense of accomplishment that comes through cooperative teamwork leads to justifiable cohesive pride (Simpkins, 1982), which in turn is critical for confirmation of job satisfaction in teaching, and for maintaining overall morale. Demonstrating enthusiasm enables those who take on assigned managerial duties to contribute greatly in fostering a positive climate and maintaining high morale levels. The principle of enthusiasm which is very important in the context of human relations such as schools must be embodied in the real performance of principals and staff.

Providing challenges to all participants will greatly increase morale and promote the climate. Provided it is accompanied by proper support and recognition, more responsible assignment of tasks can indicate achievement (Sisk, 1973) Maintaining visibility allows responsible management staff to contribute directly to the school's climate and morale. Symbolic and cultural power requires the actual physical presence of the principal, for example, walking around the school and being seen interacting with staff and students, making presentations at a formal meeting, or publicly rewarding individuals for special contributions consistent with the school ethos, such as assist in an accident or show politeness in public. Sharing the mission of private Islamic universities with students is equally important both formally and informally. So that in the application of the Role of Organizational Motivation through Fostering Climate and Morale (Climate and Moral Development) in the 4.0 era as it is now, it will soon be realized properly and smoothly.

I. Constraints in the Management of Private Islamic Universities in Maintaining the Existence of Their Institutions in Era 4.0

Private higher education institutions which are higher education institutions equivalent to higher education institutions organized by the government. So the gait of private educational institutions cannot be separated from the leadership of the professional managers of private Islamic higher education institutions full of motivation. This means that this is the same as state Islamic universities, they play a major role in educating the nation's children. The same thing is of course what is expected and has the same priority, but the reality in the field, from various private Islamic higher education institutions managed by legal entities, individuals or foundations or community organizations always gets less attention from their managers, what is expected is sometimes still far away. than what had been expected. The Quality Assurance Institute, which in the 4.0 era needed a special strategy to ensure the existence of a university, has recently emerged actually to bridge the pace of the institution's journey to serve, control and evaluate the existence of the institution (Yasin, 2017). 
The needs of this institution must of course have the support of the academic community together towards a unified whole full of motivation. The vision and mission of an educational institution, especially in private Islamic higher education institutions that are launched and expected by certain foundations or organizations that handle educational institutions, must be seen from the quality assurance institutional management model they manage. To keep it going well. Likewise, the control carried out by the government through accreditation in private Islamic tertiary institutions, namely by the National Accreditation Board for Higher Education (BAN PT) is a necessity for certain institutions or agencies, because through field assessments (online/offline) about the existence of these institutions deserves recognition internationally. nationally (accredited), with the hope that the community as users will not experience disappointment when taking the education process at a certain educational institution. So that from the constraints of managing private Islamic universities in maintaining the existence of their institutions in Era 4.0, it is expected that university managers must be able to answer these challenges with various tricks/solutions that can provide satisfaction for the creation of a motivated college environment. As a result, the obstacle that can be used as a unique and interesting term is the unaccredited constraint of a private Islamic higher education institution in Indonesia, where when the university is not accredited it cannot graduate its students.

In addition, the problem of incompetent human resources has led to a decrease in the interest of the community to join certain higher education institutions. So in this case, it is necessary to have superior human resource management where university managers must be able to manage professional human resources. Of all the resources available in the organization, human resources are the most important and very decisive. All potentials possessed by human resources greatly affect the organization's efforts in achieving goals (Abdullah, 2017). The same thing as research by (Akbar \& Noviani, 2019) that today in an all-digital era, it is a challenge for private Islamic higher education institutions that exist in Indonesia, for example in terms of Educational Technology which in general can be interpreted as the application of technology for educational activities. . And the most important thing here is the integration process between people, ideas, organizations and equipment used in the lecture process. Based on this assumption, educational technology can be interpreted as a logical, systematic, and scientific approach in educational activities. The development of educational technology is currently experiencing rapid changes, especially in the field of education. The use of ICT in education often faces several obstacles, including: the lack of procurement of ICT infrastructure in various regions, the use of used technology devices, the lack of legal instruments in the ICT field, and the high cost of procurement and use of ICT facilities. To solve the problems mentioned above, there needs to be a solution as a condition for the successful application of ICT in the learning process, namely human resources/lecturers/teachers and students must have access to digital technology and the internet in schools, interactive learning materials that use computerization, lecturers must also 
have access to digital technology and the internet. the ability and skills to use digital tools, besides that it is also necessary to have an adequate budget to procure, develop, and maintain facilities and infrastructure and the support from all parties, both university leaders, lecturers, students in implementing ICT learning for universities.

\section{J. Solutions Offered to Overcome Obstacles in Implementing Organizational} Motivation in Universities

As an answer to obstacles in the application of organizational motivation in a private Islamic higher education institution, it can be overcome through improvements in private Islamic higher education by creating an ideal university through evaluation and propositions against PTKI in Indonesia (Wanto, 2018). In addition, there are several tricks in overcoming obstacles in terms of Employee Work Motivation, including as explained by (Isni Rahayu, 2017) that there are several things that employee motivation decreases due to several things including: 1) There is no development; 2) Micromanagement; 3) Distrust of company leaders; 4) Job insecurity; 5) Poor communication with superiors; 6) Uncomfortable work environment; and 7)) Bored. So that what becomes the most supportive thing in a job is the work motivation of HR/teachers/lecturers/educational staff. Employees' work motivation is sometimes even questioned since the interview stage. Companies can assess whether or not someone is worthy to be part of the company by knowing someone's motivation to get the job. As time goes by and the dynamics it is found that an employee (lecturer and education staff) in his work, employee motivation can also decrease. Various problems may arise and trigger things like this. When the employee's work motivation has decreased, of course it will have a bad effect on the work performance of the employee.

In the world of work, when there is no progress in carrying out a job, this is what will eventually become stuck in a state of a company/educational institution. Meanwhile, the managers of private Islamic universities in this case expect to develop together with these institutions. When HR (Lecturers and Education Personnel) at a university have many of your ideas and ideas that cannot be realized by educational institutions, that's where employee motivation begins to decline.

Furthermore, related to Micromanagement, namely the situation when a superior has a leadership style with excessive supervision and direction (possessive) towards his subordinates. As a subordinate who finds a boss like this, it is natural that there will be a decrease in employee motivation. The HR (Lecturers and Education Personnel) at a university feel intimidated and also limited in doing many things. In addition, HR (Lecturers and Education Personnel) in a university also cannot develop their potential because they are too limited by orders from superiors. This type of leadership is very likely to reduce employee motivation and harm companies/educational institutions. Overcoming a boss like this might be difficult, but if companies/educational institutions can start trying by trying to work as much as possible and show the potential of an HR (subordinates) by working as much as possible For this reason, HR (Lecturers and 
Education Personnel) do not hesitate to voice their ideas, try to be confident in the work they are doing. When leaders with micromanagement have begun to be able to open their minds and receive input from employees, of course employee motivation will also increase.

Leadership Style and When to Apply Distrust in the leadership of certain private Islamic higher education institutions about employee work motivation, this can be seen from how HR (Lecturers and Education Personnel) know and love the leadership of higher education institutions, this is not an important thing that will add comfort HR (Lecturers and Education Personnel) at work. On the other hand, it is precisely the belief about whether or not a leader of an educational institution is competent that can affect the work motivation of his employees. When they lose trust in the company, employee loyalty begins to be tested and doubts begin to make HR (Lecturers and Education Personnel) work half-heartedly (sak Enake dewek). This shows that there is a decrease in employee work motivation. Trust is not something you can build on your own. However, in order to restore the work motivation of HR (Lecturers and Education Personnel) in a higher education environment, try to get to know the leaders of companies that you previously thought were less competent in leading a higher education institution. Each company leader may have different characters and competencies. When you can't show it directly and transmit motivation to its employees, it doesn't mean that the leader doesn't have the positive things that make him worthy of being a company leader.

Furthermore, job insecurity arises when the employee's work motivation, in this case human resources (lecturers and education staff) at a private Islamic higher education institution, is in an unstable state, it is very possible to decrease employee motivation HR (Lecturers and Education Personnel) will be more busy preparing to find new jobs and spend more time discussing rumors about company instability with their HR colleagues (Lecturers and Education Personnel). It is very difficult to maintain employee motivation in times of crisis like this. However, there are other better things that HR (Lecturers and Education Personnel) can do than follow the path of decreasing employee motivation and bringing the company closer to bankruptcy (bankruptcy). Preparing for the worst is not wrong, but to maintain work motivation as long as it is the responsibility of HR to do so. Especially if an employee is a leader or influential person for other employees, by giving an example to keep working optimally under any circumstances, the work motivation of other employees will also increase again. Poor communication with superiors, employee motivation, information that is not conveyed to employees will lead to rumors that ultimately make employees confused and frustrated. This of course can also trigger a decrease in employee motivation. Especially if employees do not have access to sufficient communication with superiors for clarification.

Furthermore, poor communication with superiors can indeed trigger a decrease in employee motivation. Employees who make mistakes must try to correct their mistakes without ever knowing where the fault lies, in the end, more and more mistakes are made. Even though you find it difficult to maintain good communication with your boss, then try to promote good 
communication with other co-workers. Communication with co-workers is also important, because co-workers can also increase employee motivation. HR (Lecturers and Education Personnel) can also share various things about work.

Associated with a less comfortable work environment, employee motivation when getting a comfortable work environment is closely related to maintaining good communication with coworkers. When communication and association with co-workers does not go well, of course HR (Lecturers and Education Personnel) will not feel a comfortable work environment. The comfort of this work environment is very influential on employee motivation. When you feel uncomfortable, of course, employees' work motivation will begin to decrease and vice versa employee work motivation will continue to increase by increasing the comfort of the work environment. Creating a comfortable work environment is not an individual task but must be done jointly by every worker. The way to start improving a work environment that is already uncomfortable is to improve communication with coworkers. Every change will be easier if you start from yourself.

Obstacles in overcoming boredom in employee work motivation, this is what most often reduces employee work motivation, namely boredom at work. Boredom as a cause of decreased employee motivation can be the most difficult thing to overcome but can also be the easiest thing to overcome. The reason is when it arises from oneself so that the individual must know how to overcome it. Private Islamic higher education institutions are only tasked with maintaining and protecting their human resources (lecturers and education staff) so they don't feel bored and employee motivation is maintained. However, what needs to be underlined is that the boredom of different people still allows employees to feel bored. The solution in overcoming boredom at work is to motivate yourself. For that to be happier in the office Many factors, both internal and external, affect employee work motivation. The company does have a duty to keep employees' work motivation awake. However, the role of this company will not be realized without the efforts of its employees who want to teach their own work motivation. The realization of work comfort is also a shared task (Isni Rahayu, 2017).

\section{CONCLUSION}

Based on the discussion above about the Urgency of the Role of Organizational Motivation in Managing Private Islamic Educational Institutions in Era 4.0, the following conclusions can be drawn: 1). Implementation of the Role of Motivation in an Organization by managers of private Islamic universities in Managing Private Islamic Educational Institutions in Era 4.0 so that they still exist and are able to compete can be applied through the provision of motivation. This motivation can be given to subordinates in such a way that they are willing to work sincerely for the achievement of organizational goals efficiently and economically. In addition, supporting wages for employees also make their own motivation, where specifically, wages or income have been shown to have a motivating effect, and are often associated with various self-esteem needs such as status and 
community recognition, which are considered as motivators. While wages for employees are also very necessary to achieve a sense of security and fulfill their physiological needs. As for the benefits of the role of motivation in an organization, it can be used to motivate, especially related to work behavior by utilizing internal and external factors that will start and maintain the work of participants for whom the manager of the private Islamic higher education institution is responsible, especially for lecturers and students. 2). Obstacles faced by managers of private Islamic universities in maintaining the existence of their institutions in Era 4.0 are related to quality assurance of private Islamic higher education institutions through university accreditation which is still minimal, for this reason this is also needed to minimize these shortcomings. The second is related to the professionalism of human resources and higher education managers, this is what makes private Islamic universities that exist in Indonesia weak in terms of the lack of professional and competent teaching staff (HR) in accordance with their respective duties. and the third is related to the use of ICT in learning, as well as university services so that this needs to be improved to support the two things mentioned above (Utilization of institutional digitization and institutional services). 3). The solutions offered to overcome the related obstacles in order to maintain the existence of private Islamic higher education institutions in this all-digital era (4.0) can be done through the provision of the Role of Organizational Motivation by the leaders of the universities concerned in Managing Private Islamic Education Institutions in Era 4.0 which are superior innovative and able to compete with other higher education institutions.

\section{RECOMMENDATION}

A manager in this case the leader of a private Islamic university should when providing motivation to his subordinates to improve performance in an organization is carried out gradually and consistently and continuously. So as to produce a good vision and mission direction for the universities it manages, which can produce quality private Islamic higher education institutions that are humanist at the forefront of quality, especially in Indonesia and more specifically for private Islamic higher education institutions which are currently increasingly established for compete in a healthy manner towards an advanced Indonesia gemah ripah loh jinawi toto tentrem kerto raharjo in the field of education. 


\section{REFERENCES}

Abdullah, H. (2017). Peranan Manajemen Sumberdaya Manusia Dalam Organisasi. Warta Dharmawangsa, O(51), Article 51. Https:/ / Doi.Org/ 10.46576/Wdw.V0i51.243

Akbar, A., \& Noviani, N. (2019). Tantangan Dan Solusi Dalam Perkembangan Teknologi Pendidikan Di Indonesia. Prosiding Seminar Nasional Program Pascasarjana Universitas Pgri Palembang, $O(0)$, Article Https://Jurnal.UnivpgriPalembang.Ac.Id/Index.Php/Prosidingpps/Article/View/2927

Amirudin, A. (2017). Peranan Manajemen Perguruan Tinggi Dan Implementasinya Di Fakultas Agama Islam (Fai) Unsika. Jurnal Pendidikan Islam Rabbani, 1(1), Article 1. Https://Journal.Unsika.Ac.Id/Index.Php/Rabbani/Article/View/769

Cahyorinartri, N. (2018). Motivasi Mahasiswa Berorganisasi Di Kampus. Jurnal Psikologi Insight, 2(2), 27-38. Https:/ / Doi.Org/ 10.17509/Insight.V2i2.14158

Emda, A. (2018). Kedudukan Motivasi Belajar Siswa Dalam Pembelajaran. Lantanida Journal, $5(2)$ $172-182$. Https:/ / Doi.Org/ 10.22373/Lj.V5i2.2838

Fahrurrozi, F. (2017). Kontribusi Perguruan Tinggi Islam Swasta Terhadap Pengembangan Pendidikan Islam. Fondatia, 1(2), 166-187. Https:/ / Doi.Org/ 10.36088/Fondatia.V1i2.108

Habibie, F. H. (2015). Peran Dosen Dan Pendekatannya Pada Tatap Muka Di Kelas Dalam Tiga Minggu Pertama Perkuliahan. Jurnal Ilmiah Pariwisata, 20(1), 1-13.

Isni Rahayu, M. (2017, December 17). 7 Cara Mengatasi Kurangnya Motivasi Kerja Karyawan. Glints Blog. Https:/ / Glints.Com/Id/Lowongan/Cara-Mengatasi-KurangnyaMotivasi-Kerja-Karyawan/

Johanes, J. (2018). Peran Dosen Pada Pembelajaran Student Centered Learning. Forum Ilmiah, 15(1), Article 1. Https:/ /Ejurnal.Esaunggul.Ac.Id/Index.Php/Formil/Article/View/2 1 53

Kasim, M. (2014). Entingnya Motivasi Dan Minat Terhadap Manajemen Kinerja Guru Dalam Pelaksanaan Pembelajaran Pendidikan Jasmani, Olahraga Dan Kesehatan. Academica, 3(2), Article 2. Http: / /Jurnal.Untad.Ac.Id/Jurnal/Index.Php/Academica/Article/Vie $\mathrm{w} / 2285$

Lubis, A. F., \& Pratama, R. (2021). Implementasi Kampus Islami Atas Mutu Pendidikan Pada Perguruan Tinggi Muhammadiyah (Studi Kasus Di Universitas Muhammadiyah Jakarta). Al Amin: Jurnal Kajian Ilmu Dan Budaya Islam, 4(01), 34-48. Https:/ / Doi.Org/ 10.36670/Alamin.V4i01.80

Margono. (2014). Mendorong Partisipasi Belajar Mahasiswa. Jurnal Ilmu Pendidikan, 20(2), Article

2.

Https:/ / Doi.Org/ 10.17977/Jip.V20i2.4610 
Muslih, B. (2020). Urgensi Komunikasi Dalam Menumbuhkan Motivasi Di Era Pandemi Covid-19. Jurnal Penelitian Manajemen Terapan (Penataran), 5(1), 57-65.

Prafitri, G. R., \& Damayanti, M. (2016). Kapasitas Kelembagaan Dalam Pengembangan Desa Wisata (Studi Kasus: Desa Wisata Ketenger, Banyumas). Jurnal Pengembangan Kota, 4(1), 76-86. Https://Doi.Org/10.14710/Jpk.4.1.76-86

Putri, E. N., Nuringwahyu, S., \& Hardati, R. N. (2019). Eranan Motivasi Dalam Upaya Meningkatkan Kinerja Karyawan (Studi Pada Bandung Super Model Malang). Jiagabi (Jurnal Ilmu Administrasi Niaga/Bisnis), $8(1), 26-32$.

Rusdiana, A. (2021, March 3). Hand Out Organisasi Lembaga Pendidikan Semester Genap Ta 2020/2021 [Teaching Resource]. Fakultas Tarbiyah Dan Keguruan Uin Sgd Bandung. Http://Digilib.Uinsgd.Ac.Id/38185/

Sufianti, A., \& Permana, J. (2015). Pengaruh Motivasi Kerja Dan Kompetensi Profesional Terhadap Kinerja Dosen Di Sekolah Tinggi Pariwisata Bandung. Jurnal Administrasi Pendidikan, 22(1), Article 1. Https://Doi.Org/ 10.17509/Jap.V22i1.5916

Susita, D., Parimita, W., \& Setyawati, S. (2020). Pengaruh Motivasi Kerja Dan Komitmen Organisasi Pada Kinerja Karyawan Pt X. Jrmsi - Jurnal Riset Manajemen Sains Indonesia, 11(1), 185-200. Https:// Doi.Org/ 10.21009/Jrmsi.011.1.010

Turney, C., Hatton, N., Laws, K., Sinclair, K., \& Smith, D. (1992). The School Manager (Educational Management Roles \& Tasks) The School Manager. Australia: Allen \& Unwin Pty Ltd.

Wanto, D. (2018). Kendala Dan Perbaikan Pendidikan Islam Yang Ideal. Conciencia, 18(1), 56-63. Https://Doi.Org/10.19109/Conciencia.V18i1.2439

Wulan, R. R., \& Mustam, M. (2017). Peningkatan Kualitas Pelayanan Publik Dalam Rangka Reformasi Birokrasi Di Kantor Pertanahan Kota Semarang. Journal Of Public Policy And Management Review, 6(3), 259-279. Https://Doi.Org/10.14710/Jppmr.V6i3.16740

Yasin, M. (2017). Perguruan Tinggi Agama Islam Swasta Antara Tuntutan Dan Realita. Wahana Akademika: Jurnal Studi Islam Dan Sosial, 4(1), 35-44. Https://Doi.Org/10.21580/Wa.V4i1.1477

Zairotun, S. (2019). Motivasi Kerja Di Lembaga Pendidikan Islam (Taman Kanak-Kanak Islam Terpadu Mutiara Insani Delanggu). Islamic Management: Jurnal Manajemen Pendidikan Islam, 2(02), 119-132. Https:/ / Doi.Org/ 10.30868/Im.V2i02.481 